\title{
The Roles Of Parents And Peers On Puberty In Teenagers At Mts X Banjarmasin
}

\author{
Anita Herawati ${ }^{* 1}$, Novita Dewi Iswandari ${ }^{2}$, Melati Suci Alita ${ }^{3}$ \\ \{anita.darminto@gmail.com, novitadewiiswandari@yahoo.com, melatisalita@gmail.com\} \\ ${ }^{1}$ Health Promotion Department, Faculty of Health Sari Mulia University, Banjarmasin, Indonesia, ${ }^{23}$ Midwifery \\ Department, Faculty of Health Sari Mulia University, Banjarmasin, Indonesia.

\begin{abstract}
Puberty is one of the stages of child development between 10-19 years. Parents need to prepare themselves for the changes that children will experience in puberty and peer support to determine the role of parents and peers about puberty in adolescents in MTS X Banjarmasin. This research was using the descriptive method with 60 respondents as the sample. Sampling with total sampling. The results of the research are the role of $33.3 \%$ of high school-educated fathers and $33.3 \%$ of high school-educated mothers. Father's work was $51.7 \%$ self-employed and their mother's work was housewife $48.3 \%$. Parents play a good role at $73.3 \%$ and not good $26.7 \%$. The peers play a good role was about $65 \%$ and play a less well was about $35 \%$. Concluded that most parents and peers played a good role in puberty in teenagers. Parents and peers have a very important role
\end{abstract}

Keywords : Peers, puberty, role of parents, teenager

\section{Introduction}

Adolescence is one period of human development. This period is a period of change or a transition from childhood to adulthood which includes biological changes, psychological changes and social changes. In most societies and cultures, adolescence generally begins at the age of 10-13 years and ends at the age of 18-22 years [1]

Adolescence is a period of life of biological, psychological and social changes [2]. Adolescents are residents in the age range of 10-19 years, according to the Minister of Health Regulation No. 25 of 2014, adolescents are residents in the age range of 10-18 years and according to the Population and Family Planning Agency (BKKBN) the age range of teenagers is 10-24 years and not married yet. The total age group of 10-19 years in Indonesia according to 2010 a population census was 43.5 million or around $18 \%$ of the population. In the world, it is estimated that adolescent groups number 1.2 billion or $18 \%$ of the world's population [3].

Physical growth in adolescents both men and women is very fast growth (growth spurt). At this time height growth occurs very quickly. Differences in the physical growth of men and women are in their reproductive organs, which will produce different hormones, different appearance, and different body shapes due to the development of secondary sex signs [4]. To know the various psychological demands of adolescent development and the characteristics of adolescence, it is expected that parents and adolescents themselves understand the things that must be passed during adolescence so that if adolescents are directed and can get through adolescence well then in the future adolescents will grow healthy in personality and soul. Problems that often arise are usually caused by ignorance of parents about these psychological demands, so their behavior is often not able to direct teens towards understanding their development [5].

Teenagers who are not ready for changes from within themselves can do things that are perverse such as free sex or drugs. This can cause an unhealthy young generation, even though adolescents are the next generation who 
will be the successor to the next generation who will replace the previous generation in the future? In dealing with this kind of thing, the government cooperates with BKKBN to establish adolescent family building (BKR) with counseling, seminars, and discussions about adolescent reproductive health and society in general [6].

Puberty is one of the stages of child development between 10-19 years. At this time children experience changes towards adulthood. The changes experienced are physical, mental and social changes [7]. Meanwhile, school-age children are a transition from childhood to adolescence. At this time parents have a task including preparing children to enter puberty. This is important because in adolescence children tend to be closer to their peers than with their parents. Therefore, parents need to prepare their school-age children for the changes they will experience during puberty.

\section{Research methods}

This research was conducted at MTS X Banjarmasin, South Kalimantan. This research uses a descriptive method. Descriptive research is research that only (describes) describes what is happening in a particular scene, field, or region. The population in this study were all adolescents of class VII and VIII in MTS X Banjarmasin, amounting to 60 people. This research was conducted on May 23, 2018. The sample in this study uses total sampling where the number of samples is equal to the population [8]. The reason for taking total sampling is because according to [8] a population of less than 100 entire populations is used as a research sample. Samples taken in this study were 60 students consisting of 40 students of class VII and 20 students of class VIII.

\section{Research result}

Based on research conducted on May 23, 2018, with 60 respondents, a general description of the research objects presented in the following tables is obtained:

\section{Characteristics of Respondents}

a. Based on Education

Based on the data obtained, the respondent's parents' education in MTS X Banjarmasin can be seen in the following table:

Table 4.3 Distribution of Frequency of Respondents by Education of parents in MTS X Banjarmasin

\begin{tabular}{llllll}
\hline No. & Classification & \multicolumn{3}{l}{ Parents } & \\
\cline { 3 - 6 } & & Father & $\%$ & Mother & $\%$ \\
\hline 1 & $\begin{array}{l}\text { Elementary } \\
\text { school }\end{array}$ & 10 & 16,7 & 10 & 16,7 \\
\hline 2 & Middle School & 15 & 25 & 16 & 26,7 \\
\hline 3 & High school & 20 & 33,3 & 20 & 33,3 \\
\hline 4 & Academic / PT & 15 & 25 & 14 & 23,3 \\
\hline
\end{tabular}




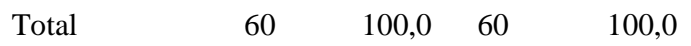

The results showed that Most parents (fathers) of respondents had a high school education, as many as 20 people $(33.3 \%)$ and the least was elementary school education, as many as 10 people (16.7\%).

The results showed that most of the parents (mothers) of respondents had a high school education, as many as 20 people (33.3\%) and the least were elementary school education, as many as 10 people (16.7\%).

b. Based on work

Based on the data obtained, the work of the respondent's parents in MTS X Banjarmasin can be seen in the following table:

Table 4.4 Distribution of Frequency of Respondents by Occupation of parents in MTS X Banjarmasin.

\begin{tabular}{llllll}
\hline No. & Classification & \multicolumn{3}{l}{ Orang Tua } & \\
\cline { 3 - 6 } & & Ayah & $\%$ & Ibu & $\%$ \\
\hline 1 & Civil servants & 16 & 26,7 & 10 & 16,7 \\
& & & & & \\
\hline 2 & entrepreneur & 31 & 51,7 & 11 & 18,3 \\
& & & & & \\
\hline 3 & housewife & - & - & 29 & 48,3 \\
& & & & & \\
\hline 4 & Etc & 13 & 21,6 & 10 & 16,7 \\
& & & & & \\
\hline & Total & 60 & 100,0 & 60 & 100,0 \\
& & & & & \\
\hline
\end{tabular}

The results showed that most of the respondents 'parents' (father) occupations were self-employed, as many as 31 people $(51.7 \%)$ and the least were etc., as many as 13 people $(21.6 \%)$.

The results showed that the most work of parents (mothers) of respondents was IRT, as many as 29 people (48.3\%) and the least were civil servants, etc., as many as 10 people (16.7\%).

2. Description of the role of parents about puberty in adolescents in MTS X Banjarmasin 
Based on data obtained about the description of the role of parents about puberty in adolescents in MTS X Banjarmasin, the following results are obtained:

Table 4.5 Frequency Distribution of Parents' Roles on Puberty in Adolescents in MTS X Banjarmasin

\begin{tabular}{llll}
\hline No. & Classification & F & $\%$ \\
\hline 1 & Well & 44 & 73,3 \\
2 & Not good & 16 & 26,7 \\
\hline & Total & Total & 100,0 \\
\hline
\end{tabular}

The results showed that parents have a good role in puberty in adolescents as many as 44 respondents (73.3\%) and parents have a less good role in puberty in adolescents as many as 16 respondents (26.7\%).

3. Description of the role of peers about puberty in adolescents in MTS X Banjarmasin

Based on data obtained about the description of the role of peers about puberty in adolescents in MTS X Banjarmasin, the following results are obtained:

Table 4.6 Frequency Distribution of Peer Roles on Puberty in Adolescents in MTS X Banjarmasin.

\begin{tabular}{clcc}
\hline No. & Classification & F & $\%$ \\
\hline 1 & Well & 39 & 65 \\
2 & Not good & 21 & 35 \\
\hline & Total & Total & 100,0 \\
\hline
\end{tabular}

The results showed that parents have a good role in puberty in adolescents as many as 39 respondents (65\%) and parents have a less good role in puberty in adolescents as many as 21 respondents (35\%).

\section{Discussion}

Based on the results of research conducted on 60 respondents about the Role of Parents and Peers about Puberty in adolescents in MTS X Banjarmasin obtained the following results:

1. Parental Characteristics based on Education and Employment

a. Characteristics of Parents based on Education

The results showed that most parents (fathers) of respondents had a high school education, which was 20 people (33.3\%) and at least elementary school education, which was 10 people (16.7\%). 
The results showed that most of the parents (mothers) of respondents had a high school education, namely as many as 20 people (33.3\%) and the least was elementary school education, as many as 10 people (16.7\%).

According to [9]. The level of education also influences the role of parents to adolescents. The higher the education of parents the more rich information and knowledge that can be applied to adolescents. Parents are required to provide guidance and direction to their children. Parents need to instill the importance of education and knowledge they get in school, outside of school and in the family.

b. Characteristics of Parents based on Occupation

The results showed that most of the occupation of parents (fathers) of respondents was self-employed, as many as 31 people $(51.7 \%)$ and the least were etc., as many as 13 people $(21.6 \%)$.

The results showed that the most work of parents (mothers) of respondents were IRT, as many as 29 people $(48.3 \%)$ and the least were civil servants, etc., as many as 10 people $(16.7 \%)$.

Opinions expressed Sukmadinata (2003), another factor that also affects one's knowledge is economic status. In meeting basic (primary) and secondary needs, families with good economic status will be more easily met than families with lower economic status. This will affect the fulfillment of the need for information knowledge including secondary needs

2. Description of the Role of Parents on Puberty in Teenagers

The results of the study conducted on 60 respondents, showed that the role of parents about puberty in adolescents in MTS X Banjarmasin with the Good category was 44 respondents (73.3\%), the Poor category was 16 respondents $(26.7 \%)$.

The role of parents as a starting point for the process of self-identification for adolescents can influence the development of adolescent souls. Parents have a big role in providing information about development in adolescents, therefore, parents are expected to provide emotional support so that adolescents feel comfortable and are not afraid to experience development [10].

This is in line with research conducted [11]. Suggesting that most of the roles of parents in the quite a category is $59.9 \%$ and the moderate category is $61.5 \%$ so that there is a Relationship between the Roles of Parents with Youth's Knowledge of the Changes of Times Young Women Puberty. For this reason, parents are required to provide guidance and direction to their children. The religious values that parents instill in their children from an early age are their provisions and fortifications for dealing with changes that occur so that later they become independent, disciplined and responsible youth.

The results of the study according to the characteristics of the respondents' parents which included education that most parents with a high school education were 20 respondents (33.3\%) because of the higher level of education, a person would influence the knowledge and information that parents would give to their children and the results of the study according to the characteristics of the respondent's parents which include work that most of the work of parents (fathers) are self-employed and parents (mothers) are housewives as many as 31 respondents (51.7\%) and 29 respondents $(48.3 \%)$ This is because parents who work as entrepreneurs and housewives have more free time for their children so that they affects the role of each parent. 
The results of the analysis in the form of a questionnaire consisting of 8 questions about how the role of parents about puberty in adolescents, most respondents said that parents explained how puberty events occurred, which can be seen from 60 respondents 52 people (86\%) in question number 1 respondent answered "Yes" which means parents explain how the puberty event took place and most respondents said that parents forbid them to be close to the opposite sex when it is puberty, which can be seen from 60 respondents 52 people (86\%) in question number 6 respondents answered "Yes "which means they are prohibited from being close to the opposite sex when they are experiencing puberty.

In the opinion of researchers, parents need to accompany and direct how puberty occurs because there will be many changes that will be experienced in adolescents themselves both physically and psychologically and when parents play a good role it greatly affects the knowledge of adolescents about puberty.

\section{Overview of the Role of Peers about Puberty in Teenagers}

The results of the research conducted on 60 respondents, showed that the role of peers about puberty in adolescents in MTS X Banjarmasin with the Good category was 39 respondents (65\%), the category of Not Good was 21 respondents (35\%).

Peers have several roles in the social the development process of children. [12]. The role of peers in the process of social development of children include as a friend, stimulation, a source of physical support, a source of ego support, a function of social comparison and a function of affection. The role of peers was also stated [13]. Namely providing opportunities to interact with others, control social behavior, develop skills and interests according to his age and exchange ideas.

This is in line with research conducted [14]. Which states that the role of peers in the category of Good is as much as $71.7 \%$ with moderate anxiety levels as much as $78.3 \%$ and there is a relationship between the role of peers and the the anxiety of young women at puberty in dealing with changes physical. For this reason, peer support is very important for adolescents to obtain information or matters related to reproductive health. Most teens will spend more time with their peers than with their parents discussing reproductive health issues related to puberty.

The results of the analysis in the form of a questionnaire consisting of 11 questions about how the role of peers about puberty in adolescents, most respondents said the existence of information from peers can increase knowledge about puberty, which can be seen from 60 respondents 54 people (90\%) in question number 6 respondents answered "Yes" which means

answer "Yes" which means the respondent answers honestly when asked by peers whether they have experienced puberty or not.

In the opinion of peers researchers also have an important role, because if peers have a function as a source of information this will have a good impact on social relationships and when teens are asked then they answer honestly means through teenage peers successfully learning adult morality standards such as cooperation, responsibility and honesty. 


\section{Acknowledgment}

thank you the Principal of the MTS X Banjarmasin School who has given permission and place as well as to the staff, teachers of the MTS X Banjarmasin School who helped in the research and friends who always support.

\section{References}

[1] Notoatmodjo. Health Promotion and Health Behavior. Jakarta: Rineka Cipta.(2011)

[2] Rudolp. Rudolph's Pediatric Textbook (Vol.2). Jakarta: EGC.(2014)

[3] WHO. Data and Information Center. Jakarta: Ministry of Health of The Republic of Indonesia. (2014)

[4] Dept of Health RI. Health Profile Jakarta: Ministry of the Health Republic of Indonesia.(2007)

[5] Dewi. Understanding Adolescent Physical Development. Yogyakarta: Gosyen Publishing. (2012)

[6] Maryani.The Right Way to Choose Family Planning Contraception for Women. Yogyakarta: Andi Offset. (2007)

[7] Patton \& Viner. Adolescent Health 1: Pubertal Transitions In Health. The Lancet 369 (9567), $1130-1139$. [Internet]. Available in: https://www.ncbi.nlm.nih.gov/m/pubmed/17398312/. [Accessed 03 February 2018]. (2007)

[8] Sugiyono. Statistics for Research. Bandung: CV. Alfabeta. (2007)

[9] BKKBN. About Education Level. (2008)

[10] Aryani. Adolescent Health Problems and Solutions. Jakarta: Salemba Medika.(2010)

[11] Munandari, Astri. The Relationship between the Role of Parents with Knowledge of Puberty Changes in Young Women in Muntilan. Thesis. Yogyakarta: Aisyiyah College of Health Sciences. [Internet]. Available in: http://digilib.unisayogya.ac.id/757/. [Accessed February 20, 2018]. (2012)

[12] Santrock. Adolescence: Youth Development Sixth Edition. Jakarta: Erlangga.(2003)

[13] Yusuf. Instructional Communication: theory and practice. Jakarta: PT. Earth Literacy.(2010)

[14] Christina, Titin. The Relationship of Peers 'Roles with Adolescent Girls' Anxiety during Puberty in Facing Physical Change in Betania Private Middle School Medan. Thesis. Medan: Faculty of Nursing, University of North Sumatra. [Internet]. Available at: https://text-id.123dok.com. [Accessed July 4, 2018]. (2014) 
